UDK 639.111.7:630*45(497.6)

\title{
ŠTETE OD MRKOG MEDVJEDA (URSUS ARCTOS L.) NA ŠUMSKIM SASTOJINAMA U SREDNJOBOSANSKOM KANTONU*
}

\section{Brown bear (Ursus arctos L.) damages at forest stands in Central Bosnia Canton}

\author{
Saša Kunovac ${ }^{1}$, Mustafa Bašić ${ }^{2}$, Nino Skrobo ${ }^{3}$, Slobodan Ličanin ${ }^{4}$
}

\begin{abstract}
Brown bear (Ursus arctos L.) is the largest carnivore species in Bosnia and Herzegovina. Due to its conflict with humans this species become extinct in many European countries centuries ago. In Bosnia and Herzegovina, an intensive bear management has been present since 1955. Supplemental feeding was the most significant characteristic of this management in order to reduce the damage to livestock, orchards and crops.

First significant occurrence of bark stripping caused by brown bear happened in 1983 . Some studies and papers lead to the conclusion that lack of some mineral ingredients in the bear food caused massive bark-stripping at forest stands. Others quoted high density of bears in certain areas as a possible cause.

Drastic reduction in the bear numbers during the period from 1992 to 1995, and lack of any management (supplemental feeding) till 1998, has resulted in the absence of damages or the damages were not reported.

New significant damages occurred in 2006 in the Vlašić region and this year in the Koprivnica region.

In this paper, we processed and analyzed the intensity, time and place of the damages caused by Brown bear (Ursus arctos L.) at two localities in Central Bosnia Canton. We compared the previous damage data (till 1992) with the current data. We also discussed possible causes, prevention and protection measures, and their efficiency and consequences to forest stands.
\end{abstract}

$\underline{\text { Kev words: }}$ Brown bear, Ursus arctos, bark-stripping, damage, tree, Koprivnica, Vlašić

\footnotetext{
* Rad prezentiran na međunarodnoj naučnoj Konferenciji "Šumarska nauka između ekonomije i zahtjeva društva", povodom 60. godišnjice Šumarskog fakulta Univerziteta u Sarajevu, Sarajevo, hotel "Hollywood" 8 - 10.10.2008. godine

${ }^{1}$ Šmarski fakultet Univerziteta u Sarajevu - Faculty of forestry University of Sarajevo

${ }^{2}$ Kantonalna uprava za Šumarstvo, Travnik - Cantonal Forestry Office, Travnik.

${ }^{3}$ Apsolvent Šumarskog fakulteta Univerziteta u Sarajevu -Final year student of Faculty of forestry University of Sarajevo

${ }^{4}$ Lovačko društvo «Vlašić», Travnik - Hunting Organisation «Vlašić», Travnik
} 


\section{Izvod}

Medvjed mrki (Ursus arctos L.) je najkrupnija vrsta karnivora u Bosni i Hercegovini. Usljed kompeticije za resurse sa ljudima, ova vrsta je nestala iz najvećeg broja evropskih zemalja prije više stotina godina. U Bosni i Hercegovini, intenzivno gazdovanje medvjdom provodi se od 1955. godine. Dopunsko prihranjivanje je bilo glavna karakteristika ovakvog načina gazdovanja, u pokušaju da se reduciraju štete koje medvjedi čine na stoci, usjevima, voćnjacima i pčelinjacima.

Prve značajne štete, uzrokovane guljenjem kore na stablima od medvjeda, zabilježene su 1983. godine. Neki radovi i studije iz tog vremena navodili su na zaključak da je primarni uzrok guljenja kore na stablima nedostatak mineralnih sastojaka $\mathrm{u}$ ishrani medvjeda. Drugi navode visoku koncentraciju medvjeda na lokalitetima oko hranilišta kao mogući uzrok guljenja kore na stablima.

Drastična regulacija brojnosti medvjeda u periodu 1992.-1995. godine, i nedostatak bilo kakvog gazdovanja (dopunsko prihranjiivanje), sve do 1998. godine, uzrokovalo je odsustvo šteta na sastojinama ili iste nisu bile registrovane.

Nove, značajne štete registrovane su 2006. godine u području Vlašića i 2008. godine na području Koprivnice.

U ovom radu, prikupili smo i obradili podatke o intenzitetu, vremenu i mjestu nastanka štete od medvjeda na dva lokaliteta u Srednjobosanskom kantonu. Uporedili smo prethodne podatke o štetama (do 1992. godine) sa sadašnjim. Takođe, komentarisani su mogući uzroci, mjere prevencije i zaštite, njihova efikasnost i posljedice po šumske sastojine.

Kliučne riječí: Medvjed, Ursus arctos, guljenje kore, štete, Koprivnica, Vlašić

\section{Uvod - Introduction}

Guljenje kore na stablima dio je uobičajenih životnih aktivnosti medvjeda u proljeće, početkom parenja, kao vid komunikacije između jedinki odnosno označavanja teritorije. U normalnim uslovima, ovaj vid šteta nema veći značaj u šumarstvu, s obzirom na to da se štete javljaju sporadično, a medvjedi, u pravilu, koriste ista stabla više godina na kojima samo "obnavljaju" guljenje kore. Prvi problemi nastali su promjenom načina u gazdovanju medvjedom, odnosno osnivanjem uzgojnih područja za medvjeda u Bosni i Hercegovini, sa ustaljenim sistemom prihranjivanja na hranilištima za medvjede (mrciništima).

Kao rezultat ovih mjera, uz adekvatnu zaštitu, uslijedilo je povećanje brojnosti medvjeda i koncentracija na relativno malim područjima, a negdje je gustina populacije prelazila 7 jedinki na 1000 ha.

$\mathrm{Na}$ svim hranilištima osnovne komponente prihranjivanja čine klanični konfiskati, lešine uginule stoke, eventualno divljači te kukuruz, u omjeru 85:15\%. Najveći intenzitet prihranjivanja je u proljeće, nakon zime i kasno ljeto-jesen dok još traje sezona lova na medvjede. 
Prve ozbiljnije štete zabilježene su 1983. godine na području lovišta Koprivnica. Od tada štete su se neprestano povećavale i kulminirale 1987. godine. Štete su registrovane uglavnom u krugu od $1 \mathrm{~km}$ oko hranilišta. Najčešće oštećivane vrste drveća bile su brijest, jela, smrča, jasika, bukva i iva, a rijetko bijeli i crni bor. Podaci o štetama od medvjeda iz ovog perioda su veoma varijabilni, te se u jednom slučaju navodi 38.064 oštećenih stabala, a u drugom 4.916 stabala (3)

U najvećem broju slučajeva oštećenja su bila na visini do $1,5 \mathrm{~m}$ od zemlje, a zahvatala su 30-60\% obima stabla, izuzetno i cijeli obim. Uglavnom su oštećena stabla prsnog prečnika od 25 i više $\mathrm{cm}$. Pored oguljene kore, bilo je vidljivo i ogrizanje kambijalnog sloja, što odstupa od uobičajenog načina obilježavanja teritorije. Identično oštećivanje stabala, koje su učinili medvjedi, registrovano je u Japanu i SAD (WATANABE 1973.; POlKER\&HARTWELL 1980.; 3).

Kao mjera za spriječavanje šteta poduzeto je prihranjivanje medvjeda vitaminskomineralnim smješama-peletiranom hranom. Uz ovakvu vrstu prihranjivanja izvršena je i regulacija brojnosti medvjeda u tadašnjem posebnom lovištu Koprivnica. Nestabilna politička situacija u zemlji uzrokovala je i povećan krivolov, te je došlo do drastične regulacije brojnosti medvjeda u ovom području, a i u cijeloj zemlji posebno u periodu 1992.-1995. godine. Usljed ove smanjene brojnosti i odsustva bilo kakvog sistematskog gazdovanja do 1998. godine (organizovano prihranjivanje), štete od medvjeda u poratnom periodu nisu evidentirane ili nisu prijavljivane.

Stabilizacijom situacije u zemlji došlo je i do poboljšanja u lovnom gazdovanju-obnavlja se uništena infrastruktura, ozbiljnije se pristupa planiranju gazdinskih mjera, te je u periodu 2000.-2005. godine registrovan oporavak i porast brojnosti populacije medvjeda u Bosni i Hercegovini.

Nove značajnije štete na šumskim sastojinama registrovane su 2006. i 2008. godine na području Vlašića i Koprivnice.

\section{Materijal i metode - Matherials and Methods}

Zbog različitih podataka o štetama iz ranijeg perioda, odlučili smo se na metodu totalnog premjera oštećenih stabala u oba područja. Za totalni premjer koristili smo: prečnicu-za mjerenje prsnog prečnika stabla, pantljiku (za dužinu i širinu oštećenja), a podaci su upisivani u „Obrazac za evidenciju šteta od medvjeda“ (prema S.KUNOVAC 2007.). Terenska istraživanja obavljena su u periodu maj-septembar 2008. god.

Podaci o gospodarskim jedinicama, odjelima, odsjecima i omjeru smjese vrsta drveća, preuzeti su iz Šumskoprivredne osnove „Srednjobosanske šume“ d.o.o. 
Tabela 1. Obrazac za evidenciju šteta od medvjeda

Table 1. Form for bear damage evidence

\begin{tabular}{|c|c|c|c|c|c|c|c|c|c|}
\hline \multirow[b]{2}{*}{$\begin{array}{l}\text { R. } \\
\text { br./ } \\
\text { No }\end{array}$} & \multirow[b]{2}{*}{\begin{tabular}{|} 
Vrsta \\
drveća/ \\
Tree \\
species
\end{tabular}} & \multirow[b]{2}{*}{$\begin{array}{c}\text { Prsni } \\
\text { prečnik/ } \\
\text { Breast } \\
\text { diameter }\end{array}$} & \multicolumn{7}{|c|}{ OŠTEĆENJE/DAMAGE } \\
\hline & & & $\begin{array}{l}\text { Udaljenost } \\
\text { od zemlje/ } \\
\text { Distance } \\
\text { from root }\end{array}$ & $\begin{array}{c}\text { Dužina } \\
\text { oštećenja } \\
\text { (na } \\
\text { stablu)/ } \\
\text { Length of } \\
\text { damage } \\
\text { on tree }\end{array}$ & $\begin{array}{c}\text { Širina } \\
\text { oštećenja } \\
\text { (do } 1 / 3 \\
\text { obima } \\
\text { stabla)/ } \\
\text { Width of } \\
\text { damage } \\
\text { (to } 1 / 3 \text { of } \\
\text { the tree } \\
\text { girth) }\end{array}$ & $\begin{array}{c}\text { Od } 1 / 3 \\
\text { do } 2 / 3 \\
\text { obima } \\
\text { stabla/ } \\
\text { From } \\
1 / 3-2 / 3 \\
\text { of the } \\
\text { tree } \\
\text { girth }\end{array}$ & $\begin{array}{c}\text { Preko } \\
2 / 3 \\
\text { obima } \\
\text { stable/ } \\
\text { Over } \\
2 / 3 \text { of } \\
\text { the tree } \\
\text { girth }\end{array}$ & $\begin{array}{l}\text { Prstenovano } \\
\text { stablo/ } \\
\text { Girdled tree }\end{array}$ & $\begin{array}{c}\text { Primjedba } \\
/ \text { Notes }\end{array}$ \\
\hline 1 & & & & & & & & & \\
\hline 2 & & & & & & & & & \\
\hline 3 & & & & & & & & & \\
\hline 4 & & & & & & & & & \\
\hline 5 & & & & & & & & & \\
\hline 6 & & & & & & & & & \\
\hline 7 & & & & & & & & & \\
\hline 8 & & & & & & & & & \\
\hline 9 & & & & & & & & & \\
\hline 10 & & & & & & & & & \\
\hline
\end{tabular}

Nakon premjera, sva oštećena stabla su razvrstana prema gospodarskim jedinicama, odjelima i odsjecima, vrstama drveća i debljinskim klasama te veličini oštećenja.

Osim utvrđivanja obima šteta nastojali smo da damo odgovore na slijedeća pitanja:

o U koje vrijeme su vršene sječe u odjelima u kojima su registrovane štete?

o S Šta se iznosilo na hranilišta za vrijeme najvećeg intenziteta šteta?

o Da li su vršeni eksperimenti Poljoprivrednog fakulteta sa đubrenjem livada i pašnjaka?

o Da li je bilo sekundarnih štetočina na oštećenim stablima?

\section{Rezultati - Results}

Nakon prikupljanja i obrade podataka, utvrdili smo slijedeće:

Oštećena stabla na području Koprivnice nalaze se u GJ Prusačka rijeka, odjeli 60, 61, 63, 64 69/01, 72/03 i 73/01, te u GJ Semešnica, odjeli 59, 60/01 i 70/02.Oštećena stabla na području Vlašića nalaze se u GJGornji Ugar, odjel 102. U oba područja evidentirano je ukupno 209 stabala sa oštećenjima od medvjeda. Vrijeme nastanka šteta je druga polovina mjeseca maja (prva registrovana šteta 25.05.2008.) do septembra 2008. god. 
Tabela 2. Pregled oštećenih stabala po područjima, gospodarskim jedinicama, odjelima i vrstama drveća uz omjer smjese.

Table 2. Review of damaged trees according to areas, departments and tree species with ratio

\begin{tabular}{|c|c|c|c|c|c|c|c|}
\hline \multicolumn{8}{|c|}{$\begin{array}{c}\text { KOPRIVNICA } \\
\text { GJ Prusačka rijeka }\end{array}$} \\
\hline \multirow{2}{*}{$\begin{array}{c}\text { Redni } \\
\text { broj }\end{array}$} & \multirow{2}{*}{ Odjel/odsjek } & \multirow{2}{*}{$\begin{array}{c}\text { Oštećeno } \\
\text { stabala }\end{array}$} & \multirow{2}{*}{$\begin{array}{c}\text { Vrsta } \\
\text { drveća }\end{array}$} & \multicolumn{4}{|c|}{ Omjer smjese } \\
\hline & & & & Jela & Smrča & Ostali četinari & Lišćari \\
\hline 1. & $72 / 01$ & 64 & Jela & 51,60 & 26,15 & 10,21 & 12,04 \\
\hline 2. & $73 / 01$ & 26 & Jela & 25,34 & 13,61 & 55,24 & 5,80 \\
\hline 3. & $69 / 01$ & 6 & Jela & 29,00 & 23,00 & 34,00 & 14,00 \\
\hline 4. & 64 & 8 & Jela & 37,00 & 19,00 & 34,00 & 10,00 \\
\hline 5. & 60 & 12 & Jela & 31,55 & 20,84 & 0,15 & 47,45 \\
\hline 6. & 63 & 2 & Jela & 49,06 & 8,60 & 6,09 & 35,86 \\
\hline 7. & 61 & $3+1$ & $\begin{array}{l}\text { Jela+ } \\
\text { smrča }\end{array}$ & 46,25 & 21,40 & 1,99 & 30,37 \\
\hline \multicolumn{8}{|c|}{ GJ Semešnica } \\
\hline \multirow{2}{*}{$\begin{array}{c}\text { Redni } \\
\text { broj }\end{array}$} & \multirow{2}{*}{ Odjel/odsjek } & \multirow{2}{*}{$\begin{array}{l}\text { Oštećeno } \\
\text { stabala }\end{array}$} & \multirow{2}{*}{$\begin{array}{l}\text { Vrsta } \\
\text { drveća }\end{array}$} & \multicolumn{4}{|c|}{ Omjer smjese } \\
\hline & & & & Jela & Smrča & Ostali četinari & Lišćari \\
\hline 1. & 59 & 2 & Jela & 38,71 & 4,56 & 13,30 & 43,43 \\
\hline 2. & $60 / 01$ & 2 & Jela & 12,78 & 2,21 & 72,93 & 12,08 \\
\hline 3. & $70 / 02$ & 7 & Jela & 2,70 & 2,98 & 81,49 & 12,83 \\
\hline \multicolumn{4}{|c|}{ Ukupno: } & \multicolumn{4}{|c|}{133 oštećena stabla } \\
\hline \multicolumn{8}{|c|}{$\begin{array}{c}\text { VLAŠIĆ } \\
\text { GJ Gornji Ugar }\end{array}$} \\
\hline \multirow{2}{*}{$\begin{array}{c}\text { Redni } \\
\text { broj }\end{array}$} & \multirow{2}{*}{ Odjel/odsjek } & \multirow{2}{*}{$\begin{array}{l}\text { Oštećeno } \\
\text { stabala }\end{array}$} & \multirow{2}{*}{$\begin{array}{l}\text { Vrsta } \\
\text { drveća }\end{array}$} & \multicolumn{4}{|c|}{ Omjer smjese } \\
\hline & & & & Jela & Smrča & Ostali četinari & Lišćari \\
\hline 1. & 102 & 76 & smrča & 1,00 & 97,00 & 0,00 & 2,00 \\
\hline \multicolumn{4}{|c|}{ Ukupno: } & \multicolumn{4}{|c|}{76 oštećenih stabala } \\
\hline
\end{tabular}

Tabela 3. Pregled oštećenih stabala po debljinskim klasama

Table 3. Review of the damaged trees according to diametar class

\begin{tabular}{|l|c|c|c|c|c|c|}
\hline \multirow{2}{*}{ Područje } & \multicolumn{7}{|c|}{ Debljinska klasa } \\
\cline { 2 - 7 } & $5-10 \mathrm{~cm}$ & $11-20 \mathrm{~cm}$ & $21-30 \mathrm{~cm}$ & $31-50 \mathrm{~cm}$ & $51-80 \mathrm{~cm}$ & $>80 \mathrm{~cm}$ \\
\hline Koprivnica & 0 & 0 & 13 & $\mathbf{1 0 3}$ & 17 & 0 \\
\hline Vlašić & 0 & 1 & 20 & $\mathbf{5 5}$ & 0 & 0 \\
\hline
\end{tabular}

Najveći broj oštećenih stabala nalazi se u debljinskoj klasi 31-50 cm kod obje vrste drveća (ukupno 158 stabala). Kod jele oštećenja sežu i u debljinsku klasu 51-80 $\mathrm{cm}$, dok kod smrče oštećenja u ovoj debljinskoj klasi nisu registrovana. 


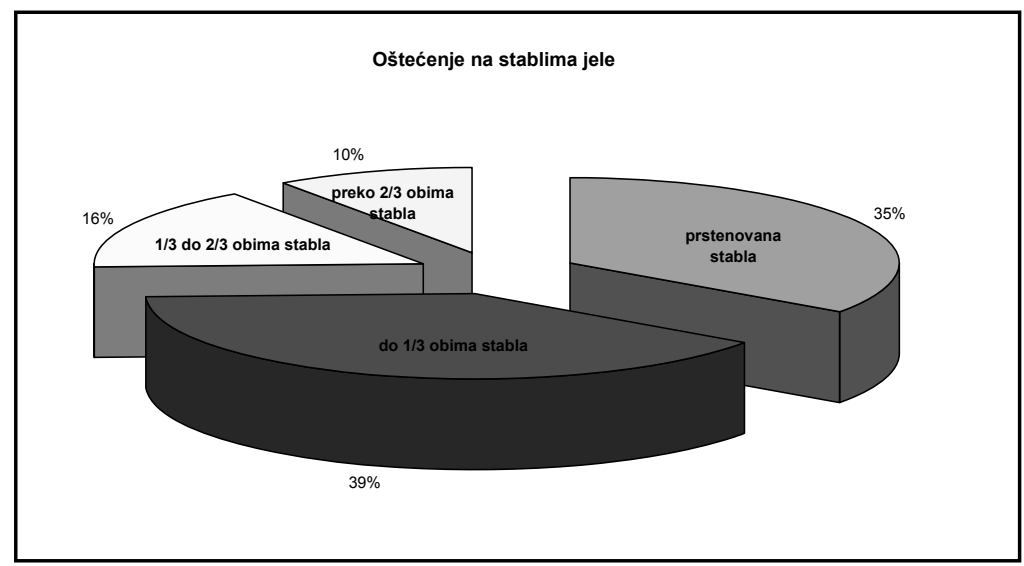

Grafikon 1. Pregled širine oštećenja u odnosu na obim stabla kod jele.

Graphic 1. Review of the damage width in relation to tree girth at fir tree.

Oštećenja na stablima razvrstali smo prema vrstama drveća, s obzirom da je na području Koprivnice oštećivana skoro isključivo jela (uz jedno stablo smrče), a na području Vlašića isključivo smrča. Oštećenja su razvrstana prema širini oštećenja na stablu, a njihov raspored po vrstama drveća prikazan je na slijedećim grafikonima:

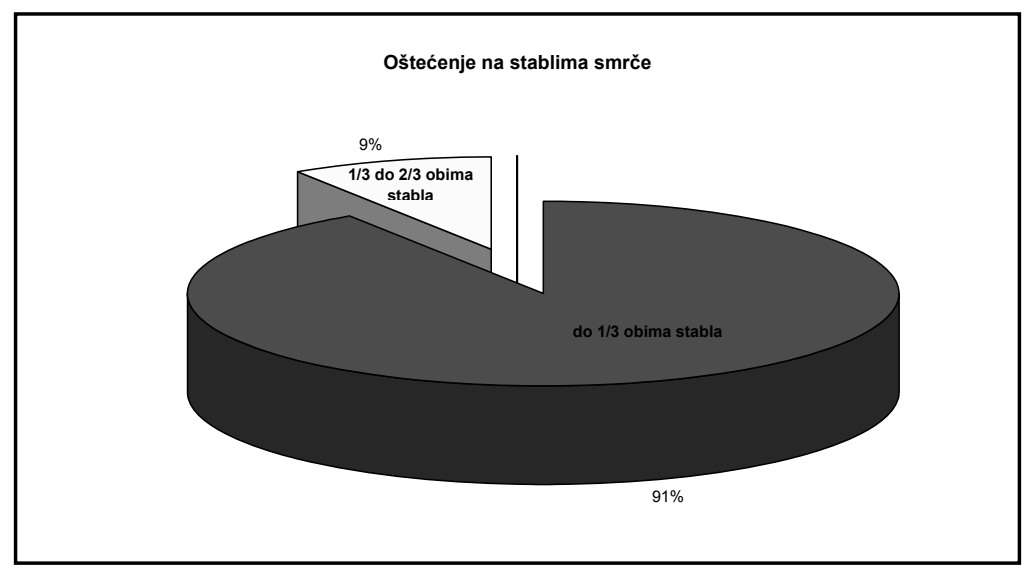

Grafikon 2. Pregled širine oštećenja u odnosu na obim stabla kod smrče.

Graphic 2. Review of the damage width in relation to tree girth at spruce.

Najveći broj stabala jele je sa oštećenjem širine do 1/3 obima stabla (53), značajan broj zauzimaju i prstenovana stabla (46), dok su oštećenja od 1/3-2/3 i preko 2/3 obima stabla nešto manje zastupljena (21 i 13 stabala). 
Kod smrče najveći broj oštećenja obuhvata do $1 / 3$ obima stabla (67), manji broj oštećenja obuhvata od $1 / 3$ do $2 / 3$ obima stabla (9), dok oštećenja preko $2 / 3$ obima stabla i prstenovana stabala nisu registrovana.

U pogledu dužine oštećenja na stablima uočljive su razlike između jele i smrče: prosječna dužina oštećenja na stablima jele iznosi 88,16 cm (raspon 20-200 cm), a kod smrče je prosječna dužina oštećenja na stablu $157,00 \mathrm{~cm}$ (raspon 40-330 cm).

Kod jele na $97 \%$ oštećenih stabala oštećenja polaze od korijena, dok ostalih $3 \%$ počinje na visini od $20 \mathrm{~cm}$ na stablu. Kod smrče takođe je najveći broj oštećenja od korijena $(80 \%)$, dok preostalih $20 \%$ počinje na prosječnoj visini od $45 \mathrm{~cm}$ na stablu.

Srednji prsni prečnik oštećenih stabala jele iznosi 40,5 cm (raspon 23-66 cm), a smrče $33,73 \mathrm{~cm}$ (raspon 18-45 cm).

Na skoro svim oštećenim stablima jele vidljivo je i ogrizanje kambijalnog sloja, odnosno uočljivi su tragovi zuba medvjeda, dok je kod smrče ova pojava manje izražena.

U području Koprivnice, radovi na iskorištavanju šuma vršeni su u godinama prije nastanka šteta (GJ Semešnica 2004. god.) i neposredno za vrijeme nastanka šteta (GJ Prusačka rijeka 2008. god.). Takođe je otvoren i novi kamenolom na lokalitetu Borovac u neposrednoj blizini oštećenih odjela. U području Vlašića vršena je doznaka i sječa slučajnih užitaka u periodu od 1997. do 2006., a 2007. godine provedena je nova doznaka i na kraju redovna sječa 2008 god.

Hranilišta za medvjede u području Koprivnice nisu smještena u odjelima u kojima su registrovana oštećenja, ali se nalaze u susjednim odjelima. U tom području su aktivna ukupno tri ovakva hranilišta. U području Vlašića hranilište se nalazi u odjelu u kojem su i registrovana oštećenja na lokalitetu Vranjevica.

U oba područja hranilišta su aktivna tokom cijele godine, odnosno na njih se stalno izlaže hrana uglavnom životinjskog porijekla: klaonični otpad, uginula stoka i rijetko i u malim količinama kukuruz u zrnu.

Eksperimenti Poljoprivrednog fakulteta vršeni su u području Koprivnice osamdesetih godina prošlog vijeka, a odnosili su se na vještačko đubrenje livada i pašnjaka, na lokalitetima Ognjilovice, Čučkovina, Pršljana, Borovca i Jelinca. Na području Vlašića nisu vršeni eksperimenti Poljoprivrednog fakulteta, ali su pojedini stočari samostalno vršili đubrenje livada i pašnjaka.

Pojava sekundarnih štetočina (insekti i patogeni) na oštećenim stablima, u vrijeme terenskih istraživanja bila je minorna - na svega 3 stabla u području Vlašića registrovano je prisustvo smrčinog pisara (Ips typhographus L.). 


\section{Diskusija i zaključak - Discussion and Conclusion}

Oštećivanje stabala od strane medvjeda, registrovano u područjima Koprivnice i Vlašića, predstavlja obnavljanje problema u načinu gazdovanja medvjedom iz osamdesetih godina prošlog vijeka. Pretpostavke o razlozima bile su razne i nisu provedena ozbiljnija istraživanja bilo o evidentiranju šteta bilo o mogućim uzrocima njihovog nastanka. Tadašnji problem pokušao se riješiti izlaganjem vitaminsko-mineralnih smješa na hranilišta za medvjede u području lovišta Koprivnica. Medvjedi su konzumirali ponuđenu hranu ali se obim šteta nije značajnije smanjio. Početkom devedesetih godina prošlog vijeka odobren je i proveden ozbiljniji zahvat $u$ populaciju medvjeda na ovom području, te su nakon njega $i$ štete postale rjeđe. Napominjemo da je u Koprivnici gustina medvjeda u vrijeme prije zahvata iznosila $i$ preko 7 jedinki na 1000 ha. Uzrok ovolikoj gustini bilo je permanentno izlaganje hrane na 12 uređenih hranilišta tokom cijele godine. Svi ostali korisnici susjednih lovišta uglavnom su izlagali hranu samo neposredno prije i za vrijeme sezone lova, čak i bez izlaganja hrane u proljeće. U Koprivnici hrana je iznošena u omjeru $85 \%$ klanični otpad i strvina $15 \%$ kukuruz.

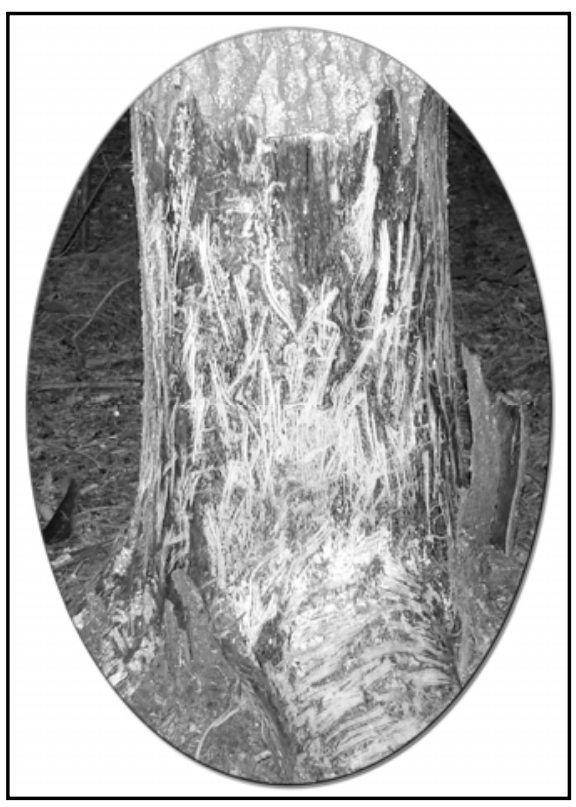

Slika 1. Oštećenje od medvjeda na jeli;

Picture 1. Bear damage on fir tree

Ogrizanje kambijalnog sloja uglavnom na stablima jele, odstupa od uobičajenog označavanja teritorije medvjeda.

Izbor vrsta drveća za oštećenja, skoro isključivo jela na području Koprivnice i isključivo smrča na području Vlašića, mogao bi se i objasniti u odjelu 102 GJ Gornji Ugar, jer je udio smrče predominantan (97\%) a jele minoran (1\%). U Koprivnici, odjeli sa najviše oštećenih stabala (72/01 i 73/01) imaju udio jele preko 51\% odnosno $25 \%$. U ostalim odjelima jela je dominantna vrsta osim odjela 70/02 u GJ Semešnica koji ima udio jele od $2,70 \%$.

Česte sječe i u većem obimu, u samom području ili blizini područja, radovi na eksploataciji kamena i bilo kakvo uznemiravanje, često tjeraju medvjede u mirna područja, te uzrokuju veću koncentraciju jedinki od normalne. Usljed stresa, posebno jači mužjaci skloni su značajnijem oštećivanju stabala jer se nalaze na teritoriji drugih mužjaka ili upozoravaju pridošlice na svoje prisustvo.

Neuravnoteženost $u$ ishrani, posebno pred i za vrijeme parenja (jaka proteinska hrana-klanični otpad i konfiskati te kukuruz), može uzrokovati „višak energije“" kod pojedinih primjeraka, te nadomjestak traže u sokovima i kambijalnom sloju drveća što opet vodi pojačanom oštećivanju stabala. 
Nakon eksperimenata Poljoprivrednog fakulteta na pomenutim lokalitetima $u$ Koprivnici, primijećeno je da su sa ovih površina potpuno nestali veliki šumski mravi (Camponotus herculeanus L.). Istovremeno, ovo su bila i područja sa najvećim intenzitetom šteta od medvjeda tokom osamdesetih godina prošlog vijeka. Tokom terenskih istraživanja u području Koprivnice registrovali smo samo sporadične mravinjake riđeg šumskog mrava (Formica rufa). Na području Vlašića, u odjelu 102, nismo registrovali ni jedan mravinjak.

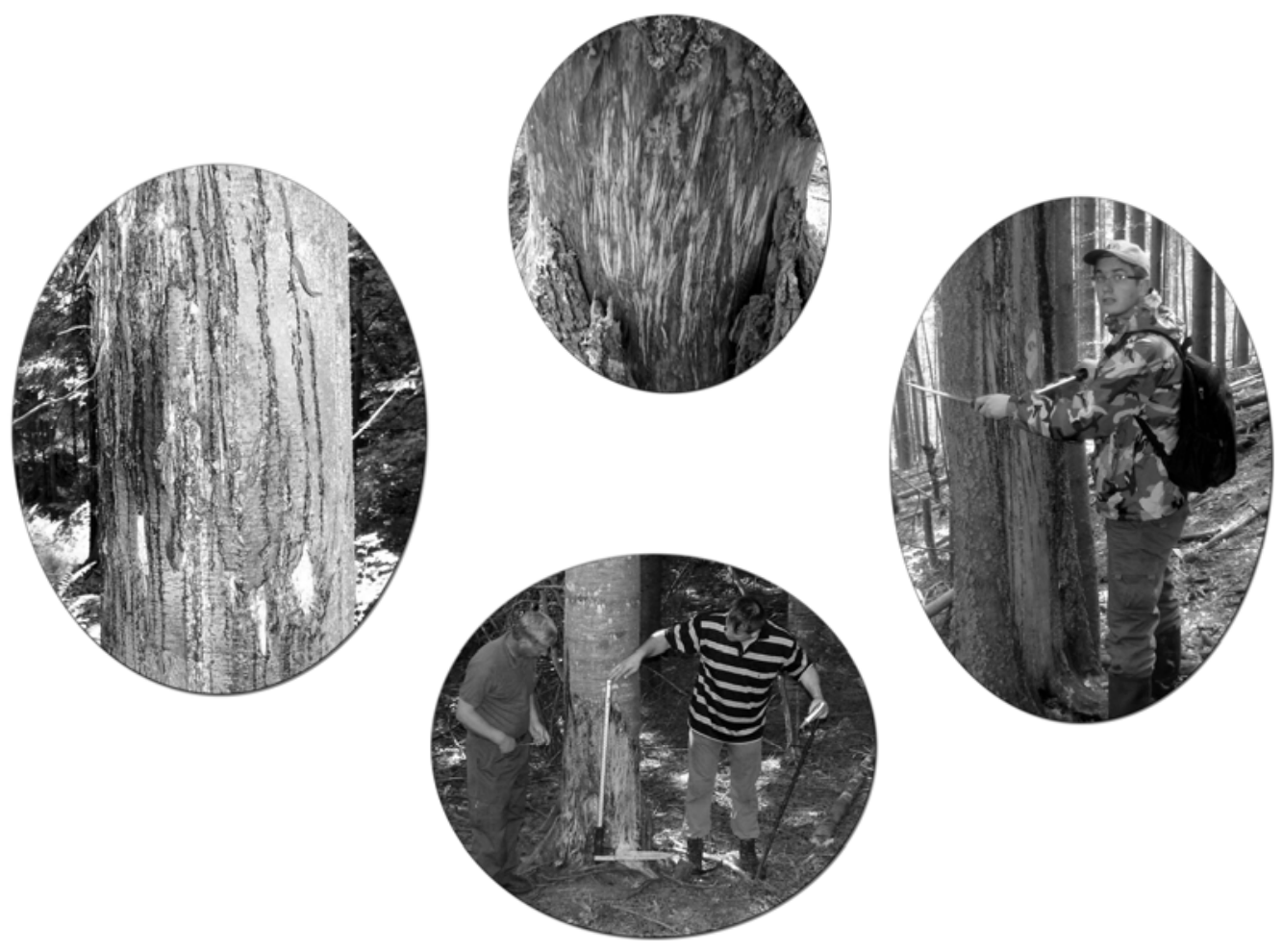

Slike 2-5. Oštećenje na smrči, jeli i mjerenje šteta.

Pictures 2-5. Damage at spruce, fir tree and measuring of the damage 


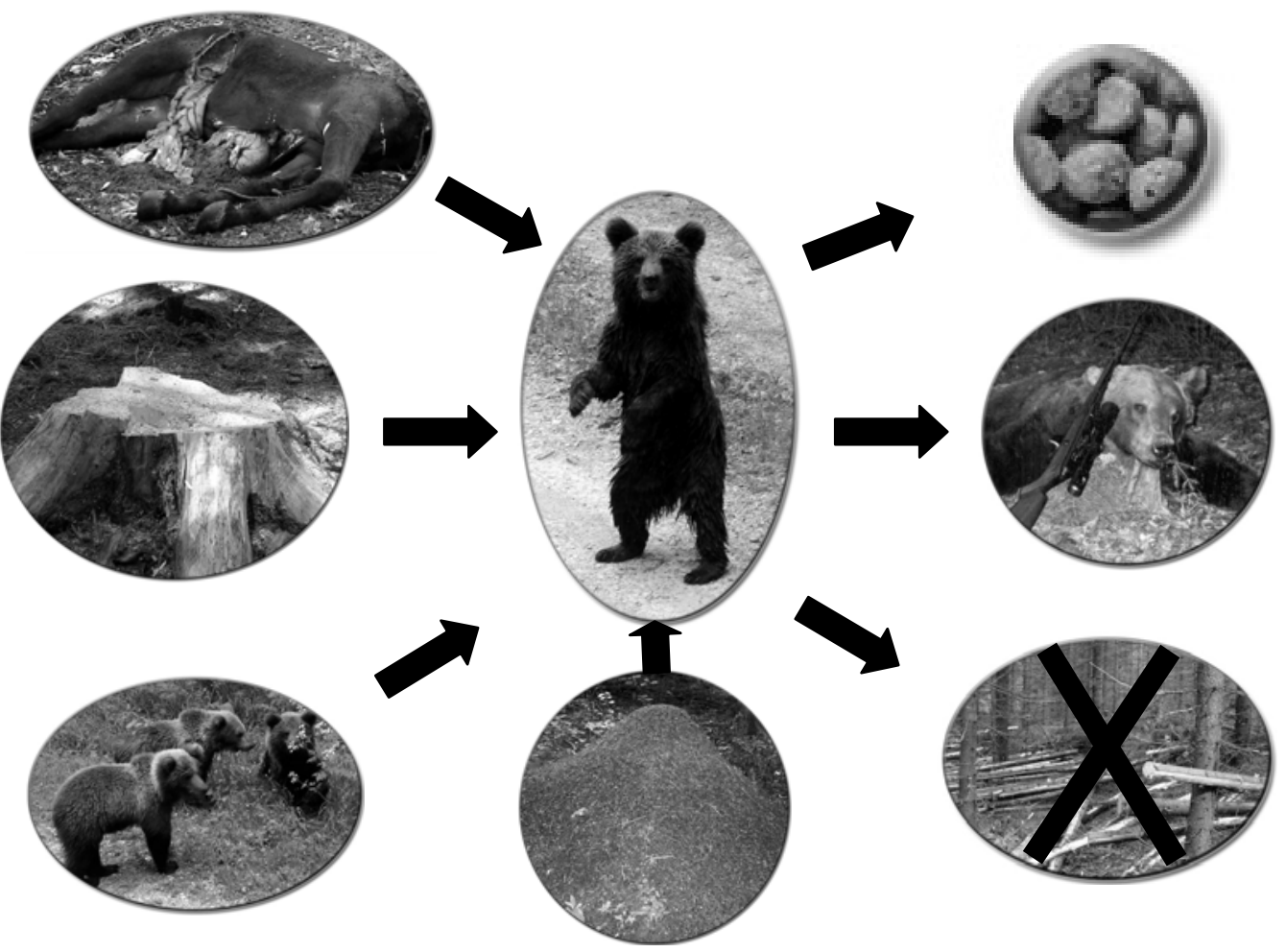

Slika 6. Mogući razlozi nastanka šteta i rješenja problema;

Picture 6. Possible causes and solutions;

Registrovana oštećenja na stablima jele i smrče predstavljaju ozbiljan problem, ako uzmemo u obzir veličinu oštećenja i oštećena stabla prema debljinskim klasama, a s obzirom na znatan udio prstenovanih stabala jele i onih oštećenih sa preko 2/3 obima stabla. Ova oštećenja, osim direktnog gubitka na kvalitetu drvne mase iziskuju i troškove ponovne doznake, sječe i izrade oštećenih stabala. Sve ovo za sobom povlači sukobe u gazdovanju između šumara i lovaca, imajući u vidu sadašnji administrativno nejasan status lovišta Koprivnica.

Minorna pojava sekundarnih štetočina u ovom području ne znači da ona ne može biti i veća ako se stvore odgovarajući uslovi. Oštećena stabla svakako predstavljaju pogodna mjesta za razvoj potkornjaka i patogena, potencijalna žarišta za njihovo dalje širenje, odnosno ulančavanje šteta.

Buduće i sadašnje obaveze korisnika lovišta da isplaćuju štetu od vrsta divljači koje imaju status zaštićenih i povremeno zaštićenih vrsta nisu male, bez obzira što se štete od medvjeda raspoređuju na Federaciju, općinu i korisnika lovišta. Štete od medvjeda na šumskim sastojinama zaslužuju ozbiljniji pristup u pogledu determinacije uzroka, kako bi se ovaj problem riješio na odgovarajući način. Mjere koje su predlagane dosada bile su slijedeće: 
- $\quad$ promijeniti način u gazdovanju sa medvjedom? - $\mathrm{u}$ odsustvu prihranjivanja javljaju se veće štete na stoci, usjevima, i pčelinjacima;

- promijeniti sastav hrane koja se izlaže na hranilišta? - vitaminsko mineralne smješe ili drugo rješenje - trenutno skupo rješenje;

- održavanje optimalne brojnosti medvjeda u području - veoma teško nemogućnost plasmana (CITES);

- $\quad$ oskladiti vrijeme i umanjiti obim iskorištavanja šuma u područjima u kojima se intenzivno gazduje medvjedom? - jako nepovoljno rješenje za šumarska preduzeća;

Samo uz odgovarajuću podršku institucija sistema, u administrativno-pravnom pogledu (rješavanje statusa lovišta), podršku naučnim istraživanjima, te primjenu novih saznanja u praksi moguće je postići odgovarajuće rješenje ovog a i ostalih problema u načinu gazdovanja medvjedom.

\section{Literatura:}

1. Caughley G., Sinclair A.R.E.,: "Wildlife Ecology and Management", Blackwell Science, Cambridge, 1994.

2. Grupa autora: Studija "Ugrožene vrste divljači u Bosni i Hercegovini", MAGA\&WALD Projekt, Banja Luka 2007.

3. Huber, D. I MoRIĆ, S. 1989. Štete od mrkih medvjeda u Jugoslaviji. Suvremeni pravci uzgoja divljači, Brioni. 3: 197-202.

4. Kunovac S., HadžIĆ I., HelJA A., LiČAnin S. I NiKICA MarelJA: „Štete od medvjeda mrkog na šumskim sastojinama u BiH“", III Simpozijum o zaštiti bilja u BiH, Neum, decembar 2006.- prezentacija.

5. NADAŽDIN M.: „Prihranjivanje medvjeda“. Zbornik radova Simpozijuma: Savremeni aspekti gajenja, zaštite i korišćenja divljači u funkciji razvoja brdsko-planinskih područja Jugoslavije“, stenografske zabilješke: 207-208, Lovački Savez Jugoslavije, Požega 1996.

6. „Podzakonski akti Zakona o lovstvu FBiH”, Službene Novine FBiH, 02/08, 08/08,13/10. Sarajevo, 2008.

7. „Zakon o Lovstvu Federacije Bosne i Hercegovine”, Službene Novine FBiH, 04/06, Sarajevo, 2006.

\section{SUMMARY - Sažetak}

In collecting the data on the damage caused by bears at forest stands we used practical bear damage evidence forms. We measured the damage at all damaged trees in two regions of the Central Bosnia Canton: Koprivnica and Vlašić. In both regions we found a total of 209 damaged trees (113 Koprivnica, 76 Vlašić). The selected tree species for the damage estimate was very strict: almost exclusively fir trees in Koprivnica and only spruce trees in Vlašić. The mean breast diameter at damaged fir trees is $40,5 \mathrm{~cm}$ and at spruce it was $33,73 \mathrm{~cm}$. The extent of the damage is very serious, especially at fir trees, almost $50 \%$ of the damaged fir trees has been damaged 
up to two thirds $(2 / 3)$ of the tree girth or completely girdled. In the Vlašić spruce trees, one third $(1 / 3)$ of the tree girth or $91 \%$ damage. The average length of damage at fir trees is $88,16 \mathrm{~cm}(20-200 \mathrm{~cm})$ and at spruce it is $157 \mathrm{~cm}(40-330 \mathrm{~cm})$. Most of the damaged trees are in the breast diameter class of $31-50 \mathrm{~cm}$ (158). Beside the simple bark stripping, teeth marks are also visible, especially at fir tree.

This damage recalls the problem that existed in the late eighties of the last century, and represents a problem in bear management. In previous times, the pellet food was used as a possible solution instead of animal carcass and meat. Bear density in those regions was over 7 animals per 1000 ha. Drastic regulation of bear numbers was approved and conducted in the early 90's. Possible cause for this kind of damage can be the density, stress, disturbance by humans (forestry, recreation, quarries, etc), and extinction of ants due to Agricultural faculty experiments or monotonous food with animal proteins.

We discussed possible measures and their application in practice:

- Management changes? - without feeding more damages to crops, orchards, beehives and livestock;

- $\quad$ Food ingredients changes? - vitamins, etc - expensive solution at the moment;

- Optimal harvesting of population/regulation of bear numbers - lack of market (CITES);

- $\quad$ Adjust time and reduce harvesting in Forestry in Bear reserves? - extremely inconvenient solution for Forest enterprises;

- $\quad$ Detail research? - yes, but supported by state institutions; 